\title{
Polymer clips (Hem-o-lok®) for renal vessel control in laparoscopic living donor nephrectomy: 12 years of experience in a Tertiary Care Center
}

\section{Uso de clips de polímero (Hem-o-lok®) para el control vascular renal en nefrectomía laparoscópica de donador vivo: 12 años de experiencia en un centro de tercer nivel}

DGerardo Tena-González-Méndez, ${ }^{1}$ CMiguel Alejandro Peña-Islas, ${ }^{1}$ CHumberto Hernández-Pañeda, ${ }^{1}$ Bernardo Gabilondo-Pliego, ${ }^{1}$ Erancisco Tomás Rodríguez-Covarrubias. ${ }^{*}$

Keywords:

Kidney transplantation,

Living donor,

Laparoscopy,

Nephrectomy, Vascular

closure devices

Corresponding author:

*Francisco Tomás

Rodríguez Covarrubias.

Vasco de Quiroga 15,

col. Belisario

Domínguez Secc 16,

Del. Tlalpan, 14080

Ciudad de México,

México. Correo elec-

trónico: frodriguez.

covarrubias@gmail.

com

\section{Abstract}

Objective: To describe our experience using polymer clips (Hem-o-lok $®$ ) for renal vessel control in laparoscopic living donor nephrectomy (LLDN).

Materials and methods: We conducted a retrospective and descriptive analysis from our database of all minimally invasive living donor nephrectomies (hand-assisted and pure laparoscopic) performed from 2008 to 2020 in our institution. We included patients who underwent LLDN using polymer clips (Hem-o-lok ${ }^{\circledR}$ ) for vascular control of renal arteries and veins, and whose clinical records were complete.

Results: 330 LLDN were performed, 183 (55.5\%) were hand-assisted nephrectomies and 147 (44.5\%) were pure laparoscopic nephrectomies. Mean warm ischemia time (WIT) was 3.98 minutes and median of estimated blood loss (EBL) was $100 \pm 140 \mathrm{ml}$. Four patients (1.2\%) required conversion to an open procedure due to vascular injury. 31 complications (9.3\%) were registered, of which 23 (6.9\%) were non-life-threatening complications. No deaths nor loss of renal grafts were reported.

Limitations: the main drawbacks of this study are its retrospective nature, and that it is limited to only one center.

Originality and value: It is a study that questions the contraindication issued by the FDA for the use of polymer clips for vascular control in LLDN, demonstrating its use is a safe and effective option.

Conclusion: The use of polymer clips, specifically Hem-o-lok ${ }^{\circledR}$, is a safe method for vascular control of the renal hilum vessels in laparoscopic living donor nephrectomies.

Citation: Tena-González-Méndez G., Peña-Islas M. A., Hernández-Pañeda H., RodríguezCovarrubias F. T. Polymer clips (Hem-o-lok $®$ ) for renal vessel control in laparoscopic living donor nephrectomy: 12 years of experience in a Tertiary Care Center. Rev Mex Urol. 2022;82(1):pp. 1-10

${ }^{1}$ Secretaría de Salud, Instituto Nacional de Ciencias Médicas y Nutrición "Salvador Zubirán". Ciudad de México, México.

Received: 21 de septiembre de 2021

Accepted: 08 de febrero de 2022

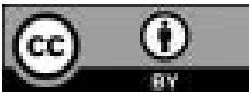




\section{Polymer clips (Hem-o-lok®) for renal vessel control in laparoscopic living donor... Tena-González-Méndez G., et al.}

\section{Resumen}

Objetivo: Describir el uso de clips de polímero (Hem-o-lok®) para el control vascular renal en nefrectomía simple de donador laparoscópica (NSL)

Materiales y Métodos: Realizamos un análisis retrospectivo y descriptivo de las nefrectomías de donador mínimamente invasivas (mano-asistidas y laparoscópicas puras) realizadas entre 2008 y 2020. Se incluyeron pacientes sometidos a NSL en las cuales se utilizaron clips de polímero (Hem-o-lok $\left.{ }^{\circledR}\right)$ para el control vascular del hilio renal. Resultados: Se realizaron 330 NSL, 183 (55\%) fueron mano asistidas y el resto laparoscópicas puras. Se obtuvo un tiempo de isquemia caliente promedio de 3.98 minutos, una pérdida de sangre promedio de $100 \pm 140 \mathrm{ml}$. Cuatro pacientes (1.2\%) ameritaron conversión a cirugía abierta debido a lesión vascular. Se registraron 31 (9.3\%) complicaciones postoperatorias de las cuales 23 (6.9\%) fueron complicaciones menores. No se reportaron muertes ni pérdidas del injerto.

Limitantes del estudio: Las principales limitantes del estudio son que se trata de un estudio retrospectivo de un solo centro.

Palabras clave:

Trasplante renal, Donante vivo, Laparoscopia, Nefrectomía, Dispositivos de cierre Originalidad o valor: Se trata un estudio que cuestiona la contraindicación emitida por la FDA para el uso de clips de polímeros para el control vascular en NSL, al mostrar ser una opción segura y efectiva. Conclusiones: El uso de clips de polímero, específicamente Hem-olok ${ }$, es un método seguro para el control vascular del hilio renal en nefrectomías laparoscópicas de donador.

\section{Background}

Kidney transplant surgery in Mexico has shown a constant growth since its beginning in 1963. In 2019, the Center of National Transplantation of Mexico reported that 2967 kidney transplants were performed nationwide, of which 2041 (68\%) were performed in living donors and 926 (31\%) in cadaveric donors. ${ }^{(1)}$

Living donor nephrectomy (LDN) is a special procedure considering that it is performed in healthy individuals, so care must be taken to reduce morbidity to a minimum. ${ }^{(1)}$ Laparos- copic living donor nephrectomy (LLDN) has replaced the open approach, due to well-known advantages such as: better pain control, shorter recovery time, shorter length of hospital stay and better cosmesis. ${ }^{(2)}$ Moreover, we and other groups have demonstrated that functional results are comparable to those of open donor-nephrectomy. ${ }^{(3)}$ However, it has some drawbacks: longer warm ischemia time (WIT) and steeper learning curve. ${ }^{(4)}$ 


\section{Polymer clips (Hem-o-lok®) for renal vessel control in laparoscopic living donor... Tena-González-Méndez G., et al.}

LLDN is a demanding procedure where vascular control is the most relevant step, in which surgeon must ensure an adequate length of renal artery and vein without compromising the donor and the graft, thus having to take action to minimize the potential of harm. There are two methods to secure the renal vessels laparoscopically: a transfixing method with staplers and a non-transfixing method with surgical clips, either of metal or self-holding polymer clips. ${ }^{(5)}$ The risk of malfunction exists with both devices: clip slippage or stapler misfire. ${ }^{(6)}$ In general, both situations are considered to be reported in the literature less frequently than actually occur. ${ }^{(7)}$ In 2006, the U.S. Food and Drug Administration (FDA) issued a recommendation against the use of polymer clips (Hem-o-lok ${ }^{\circledR}$ ) for renal vessel control in LLDN, leaving as the only alternative staples to control renal vessels. ${ }^{\left({ }^{(8)}\right.}$

Nevertheless, stapler misfire present in up to $1.7 \%$ of LLDN. ${ }^{(9)}$ Furthermore, the use of stapling devices represents higher costs for patients and healthcare systems in comparison polymer clips. For that reason, proving that the use of polymer clips is a safe and effective method for vascular control in LLDN could be a valid contribution for low- and mid-income healthcare systems or to reduce out-of-pocket expenses to patients.

The aim of our study was to describe the experience in our Tertiary-care center using polymer clips (Hem-o-lok ${ }^{\circledR}$ ) for vascular control during LLDN. ${ }^{(8)}$

\section{Materials and methods}

We conducted a retrospective and descriptive analysis from a database of both hand-assisted and pure laparoscopic living donor nephrectomies performed from 2008 to 2020 in our institution by three urologists (BGP, JKB, FRC). Study protocol was approved by the Institutional Review Board (IRB:3408) and no research funding was needed. Surgical technique always comprised thorough dissection of fatty tissue surrounding renal vessels as well as placement of 2 polymer clips on the proximal end of the vessel before sharp transection, leaving a $2 \mathrm{~mm}$ stump between clip and transection line to reduce the risk of clip displacement as Figure 1 A-D shows. 
Figure 1A-D. Example of the correct use of polymer clips in our center

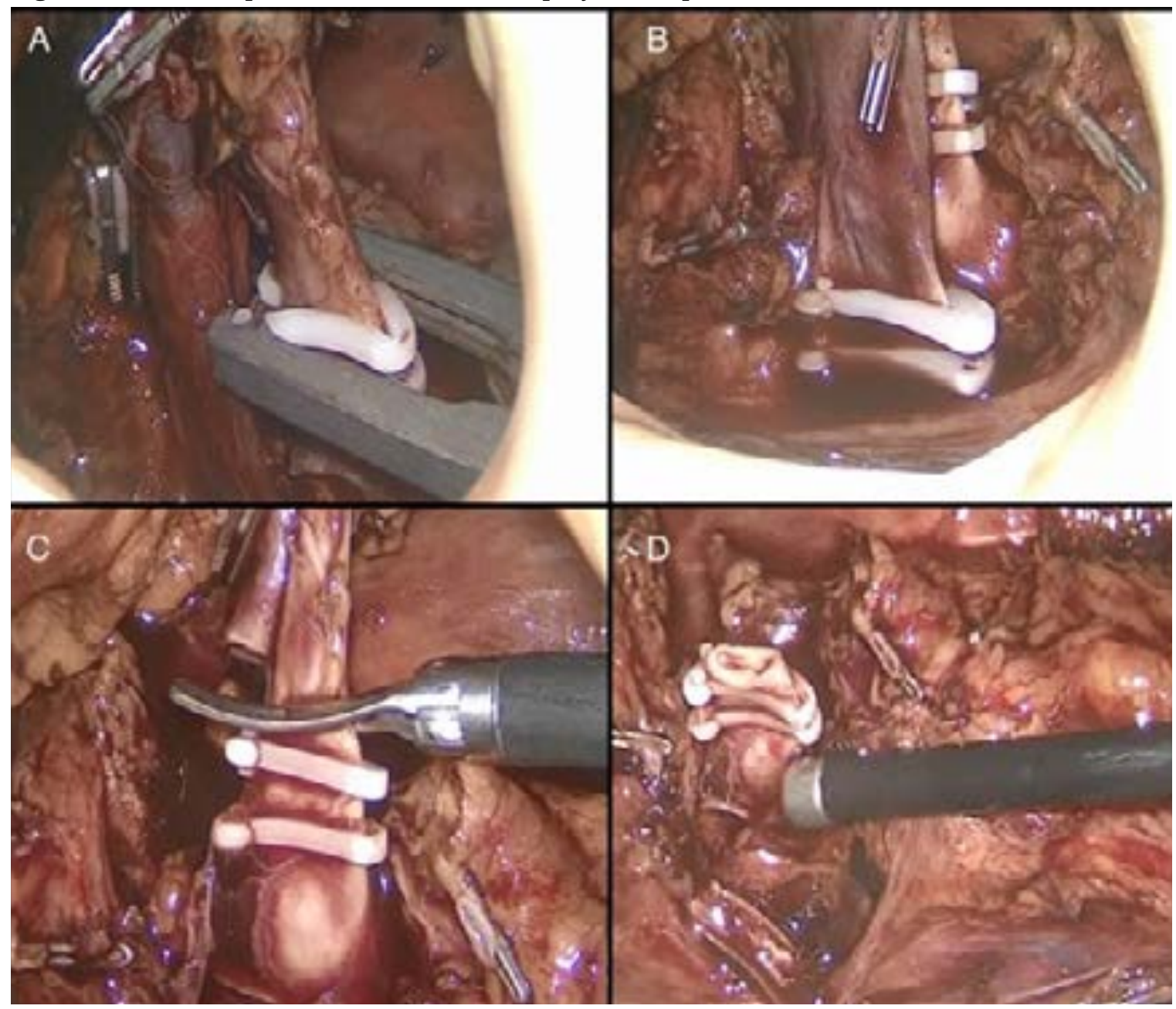

A) Circumferential dissection of renal vessels, thoroughly removing all surrounding fatty tissue as proximal as possible, with complete visualization of the clip applicator tip for ligation of renal artery; B) Placement of two clips proximally in both renal vessels (10mm clip on renal artery and $15 \mathrm{~mm}$ clip on renal vein); C) Sharp transection of the vessel after confirming correct placement and D) Leaving a $2 \mathrm{~mm}$ stump between clip and transection line to reduce the risk of clip displacement.

Variables analyzed included age, gender, body mass index (BMI), preoperative and postoperative estimated glomerular filtration rate (eGFR), preoperative and postoperative hemoglobin and hematocrit, type of minimally invasive surgery (hand-assisted or pure laparoscopic), laterality, WIT, operative time, estimated blood loss (EBL), and need for blood transfusion. We also evaluated intraoperative and 30-day postoperative complications with the modified Clavien-Dindo Classification for LLDN. ${ }^{(10)}$ The descriptive analysis was performed using SPSS v 20.0 statistical software. 


\section{Results}

A total of 380 LLDN were performed between 2008 and 2020 at our center. We excluded 50 patients due to incomplete information regarding vascular control device used or perioperative variables, leaving 330 LLDN suitable for analysis.

The median donor age was $39 \pm 18$ years (range 18-69), with 187 women (56.7\%). Mean BMI was $25.53 \mathrm{~kg} / \mathrm{m}^{2}(\mathrm{SD} 2.95)$.

\section{Preoperative data}

Mean preoperative creatinine was $0.8 \mathrm{mg} / \mathrm{dL}$ (SD 0.17) with a median eGFR of $105 \pm 23 \mathrm{ml} / \mathrm{min}$ (57-137). The mean preoperative hemoglobin was $14.9 \mathrm{~g} / \mathrm{dL}$ (SD 1.3), with a mean hematocrit of 43.84 (SD 4.06).

\section{Intraoperative data}

Two surgical techniques have been applied in LLDN throughout these twelve years at our center: at the beginning of our series 183 patients (55.5\%) underwent hand assisted LLDN; subsequently, 147 patients (44.5\%) underwent pure LLDN. The left kidney was retrieved more frequently (309 cases; 93.6\%). Mean operative time was $235 \pm 61$ minutes (range 120-156).

Mean WIT was 3.98 minutes (SD 2.022) and median EBL was 100 \pm 140 (range 10-2500). Four patients $(1.2 \%)$ required conversion to open surgery due to vascular injury. Only in one case this was secondary to polymer clip displacement. The other three cases could be explained by excessive traction at the time of kidney retrieval. In all cases, the situation was solved with intraoperative repair and blood transfusion without further complications for donors or grafts. No reoperations, graft losses or donor deaths were reported in our series (Table 1). Kidney transplantation was completed successfully in all 330 cases.

Table 1. Summary of four patients requiring conversion to open surgery

\begin{tabular}{|c|c|c|c|c|c|c|c|c|c|c|}
\hline Patient & Gender & Age & BMI & $\begin{array}{c}\text { Preop } \\
\text { eGFR } \\
(\mathrm{ml} / \\
\mathrm{min})\end{array}$ & $\begin{array}{c}\text { Preop } \\
\mathrm{Hb} \\
(\mathrm{g} / \mathrm{dL})\end{array}$ & Side & $\begin{array}{c}\text { EBL } \\
(\mathrm{ml})\end{array}$ & $\begin{array}{c}\text { Transfusion } \\
(\mathrm{Y} / \mathrm{N})\end{array}$ & $\begin{array}{c}\text { Postop } \\
\text { Hb } \\
(\mathrm{g} / \mathrm{dL})\end{array}$ & $\begin{array}{c}\text { Postop } \\
\text { eGFR } \\
(\mathrm{ml} / \mathrm{min})\end{array}$ \\
\hline 1 & Female & 33 & 26.9 & 132 & 13.6 & Left & 1200 & $\mathrm{Y}$ & 10.9 & 97 \\
\hline 2 & Female & 23 & 25.5 & 102 & 14.8 & Left & 100 & $\mathrm{~N}$ & 11.4 & 68 \\
\hline 3 & Male & 34 & 23.5 & 100 & 15.7 & Left & 2500 & $\mathrm{Y}$ & 8.4 & 49 \\
\hline 4 & Male & 30 & 24.2 & 110 & 14.9 & Left & 800 & $\mathrm{~N}$ & 12.6 & 61 \\
\hline
\end{tabular}

eGFR, estimated glomerular filtration rate; Hb, hemoglobin; EBL, estimated blood loss. 


\section{Postoperative outcomes}

Thirty one complications (9.3\%) were registered during the 30-day postoperative period, of which 23 (6.9\%) were modified Clavien-Dindo grade 1 (Non-life-threatening complications); five (1.5\%) were grade 2a complications (one pulmonary embolism, three pneumonias, and one intraabdominal abscess managed conservatively); there were only three $(0.9 \%)$ grade $2 \mathrm{~b}$ complications in two patients (one patient with a pancreatic fistula and an intraabdominal fluid collection requiring percutaneous drainage; and one patient with a pleural effusion and an intraabdominal abscess requiring thoracentesis and percutaneous drainage). Description is summarized in Table 2 . No deaths nor loss of renal grafts were reported.

Table 2. Type of complications and number of patients. (*One patient presented 2 complications)

\begin{tabular}{|c|c|c|}
\hline Complications & Patients & Modified Clavien-Dindo \\
\hline \multicolumn{3}{|l|}{ Gastrointestinal } \\
\hline Ileum and constipation & 3 & 1 \\
\hline Melena & 1 & 1 \\
\hline \multicolumn{3}{|l|}{ Respiratory } \\
\hline Pulmonary embolism & 1 & $2 \mathrm{a}$ \\
\hline Pneumonia & 3 & $2 \mathrm{a}$ \\
\hline Atelectasis and desaturation & 9 & 1 \\
\hline Pleural effusion* & 1 & $2 \mathrm{~b}$ \\
\hline \multicolumn{3}{|l|}{ Genitourinary } \\
\hline Urinary tract infection & 3 & 1 \\
\hline Epididymitis & 1 & 1 \\
\hline Acute urinary retention & 3 & 1 \\
\hline \multicolumn{3}{|l|}{ Surgical site infection } \\
\hline Seroma & 1 & 1 \\
\hline Lymphatic fistula & 1 & 1 \\
\hline $\begin{array}{r}\text { Pancreatic fistula and intraabdominal } \\
\text { fluid collection }\end{array}$ & 1 & $2 \mathrm{~b}$ \\
\hline Intraabdominal abscess* & 2 & $2 \mathrm{a} / 2 \mathrm{~b}$ \\
\hline \multicolumn{3}{|l|}{ Other Complications } \\
\hline Tramadol hypersensitivity & 1 & 1 \\
\hline \multicolumn{3}{|l|}{ Intraoperative Complications } \\
\hline Conversion to open surgery & 4 & $2 \mathrm{c}$ \\
\hline
\end{tabular}




\section{Discussion}

In any surgical procedure the goal is to perform it safely and with optimal results. For the case of living donor surgery these principles are of particular interest since it is performed in a healthy, usually young, altruistic donor. In addition, it imposes other technical difficulties such as ensuring an adequate vascular length to ease vascular anastomosis in the recipient, while reducing graft damage and ischemia. The most critical step of this surgery is a thorough dissection and control of renal vessels before transection. This can be achieved by using clips or staplers. Although both are effective methods for vascular control, failure has been reported. Nowadays, staplers are the only FDA approved method for vascular control of the renal hilum in the United States of America. However, the use of staplers is not free from complications, which have been reported to happen in $1-2 \%$ of the cases. ${ }^{(11,12)}$ In this study, we report 4 (1.2\%) out of 330 patients having vascular complications in whom vascular control was achieved with polymer clips. This rate is similar to that estimated with the use of stapling devices. In fact, Hsi et al. analyzed the FDA database on the different methods for vascular control in LLDN estimating a complication rate of $1.7 \%$ with the use of polymer clips. ${ }^{(8)}$

One of the main reasons for polymer clip dislodgment or failure in securing blood vessels is the presence of excessive fatty tissue surrounding renal vessels, which blocks the self-locking mechanism of the clip. ${ }^{(13)}$ Therefore, a refined surgical technique which fulfills the following surgical principles is of paramount relevance: 1) thorough circumferential dissection of each vessel, completely removing all surrounding fatty/lymphatic tissue; 2) full visualization of the clip applicator tip and the self-locking end of the clip; 3) application of 2 clips on the proximal end of each renal vessel; 4) confirmation of the correct clip placement before securing it and transecting the vessel; 5) sharp vessel transection leaving a remnant of at least 2 millimeters between the clip and transection line; and 6) careful withdrawal of the clip applicator. Some studies have confirmed that, if these 6 steps for the correct placement of Hem-o-loks ${ }^{\circledR}$ are followed, the use of polymer clips can be considered a safe option for vascular control of the renal hilum. ${ }^{(14,15)}$

Regarding other intraoperative characteristics in our series, mean WIT, EBL and operative time are comparable to those reported by other groups using staplers, without clinical difference. ${ }^{16-18)}$ Recently, a meta-analysis comparing the use of polymer clips and vascular staplers for donor nephrectomies found no differences in terms of mechanical failure rate, intraoperative bleeding or death confirming that the correct use of both devices is safe. ${ }^{(19)}$ Chan et al. retrospectively analyzed a series of 175 patients who underwent LLDN, with a complication rate of $14 \%$ ( $4 \%$ major complications), conversion rate of $1.7 \%$ and blood transfusion requirements of $3.4 \%{ }^{(20)}$ In comparison, our complication rate was $9.3 \%$, most of which were non-life-threatening complications (23/31 cases), the remaining complications were subject to medical management or minimally invasive procedures (thoracocenthesis and percutaneous drainage). Similarly, we reported a low conversion rate and blood transfusion requirements of only $1.2 \%$. There were no deaths nor loss of renal grafts reported among our patients. 
On the other hand, the question arises as to which option is more cost-effective and profitable in our setting. In Mexico, the cost per patient of a Covidienä endoGIA stapler with 2 vascular stapler loads is approximately $\$ 600$ USD. In contrast, the cost per patient of a reusable clip applicator plus one clip cartridge is approximately $\$ 150$ USD. Figure 2 shows the cost differences between using stapling devices compared to polymer clips after 20 procedures. Estimating a cost of $\$ 521$ USD per patient in the stapler group results in a total expense of $\$ 10,000$ USD after 20 procedures. Conversely, the estimated cost of the clip applicator is $\$ 2,000$ USD, while the cost of $10 \mathrm{~mm}$ (purple) and $15 \mathrm{~mm}$ (gold) Hem-o-lok ${ }^{\circledR}$ cartridges is \$21 and \$40 USD, respectively, resulting in an approximate expense of $\$ 3,300$ USD after 20 procedures. Therefore, when using polymer clips, we reach a cost-benefit advantage after 5-6 procedures.

Figure 2. Cost differences between staplers and polymer clips in Mexico City

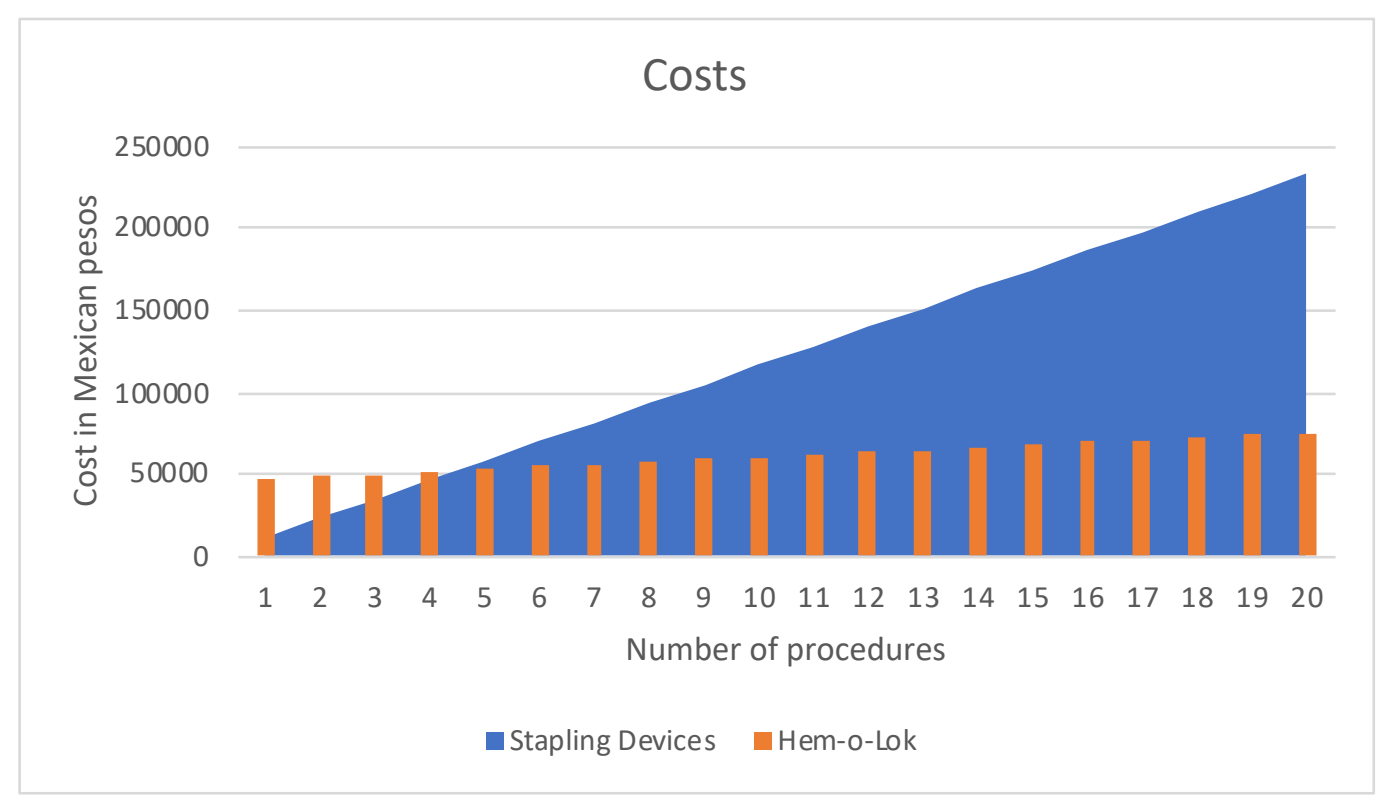

\section{Conclusions}

According to our results, the use of self-locking polymer clips is a safe method for vascular control of the renal hilum vessels in LLDN. A careful dissection and refined surgical technique are essential to avoid perioperative complications. Additionally, this method appears to be the most cost-effective option, with similar outcomes when compared to stapling devices.

\section{Financing}

No sponsorship was received to write this article. 


\section{Polymer clips (Hem-o-lok®) for renal vessel control in laparoscopic living donor... Tena-González-Méndez G., et al.}

\section{Conflict of interest}

The authors declare no conflicts of interest

\section{References}

1. Gupta N, Raina P, Kumar A. Laparoscopic donor nephrectomy. J Minim Access Surg. 2005;1(4):155-64. doi: https://doi. org/10.4103/0972-9941.19262

2. Fonouni H, Mehrabi A, Golriz M, Zeier M, Müller-Stich BP, Schemmer P, et al. Comparison of the laparoscopic versus open live donor nephrectomy: an overview of surgical complications and outcome. Langenbecks Arch Surg. 2014;399(5):543-51. doi: https://doi. org/10.1007/s00423-014-1196-4

3. Villeda-Sandoval CI, Rodríguez-Covarrubias F, Cortés-Aguilar G, Alberú-Gómez J, Vilatobá-Chapa $M$, Sotomayor $M$, et al. Hand-assisted laparoscopic versus open donor nephrectomy: a retrospective comparison of perioperative and functional results in a tertiary care center in Mexico. Transplant Proc. 2013;45(9):3220-4. doi: https://doi. org/10.1016/j.transproceed.2013.03.055

4. Razón-Gutiérrez JE, Villeda Sandoval C, Rodríguez-Covarrubias F. Experiencia en nefrectomía laparoscópica de donador en un centro de tercer nivel. Rev Mex Urol. 2011;71(3):151-5.

5. McGregor TB, Patel P, Chan G, Sener A. Hilar control during laparoscopic donor nephrectomy: Practice patterns in Canada. Canadian Urological Association Journal. 2017;11(10):321-4. doi: https://doi.org/10.5489/cuaj.4490
6. Kwazneski D, Six C, Stahlfeld K. The unacknowledged incidence of laparoscopic stapler malfunction. Surg Endosc. 2013;27(1):86-9. doi: https://doi.org/10.1007/ s00464-012-2417-y

7. Friedman AL, Peters TG, Ratner LE. Regulatory failure contributing to deaths of live kidney donors. Am J Transplant. 2012;12(4):82934. doi: https://doi.org/10.1111/j.16006143.2011.03918.x

8. Hsi RS, Ojogho ON, Baldwin DD. Analysis of techniques to secure the renal hilum during laparoscopic donor nephrectomy: review of the FDA database. Urology. 2009;74(1):142-7. doi: https://doi.org/10.1016/j.urology.2008.11.010

9. Cabello R, García JV, Quicios C, Bueno G, González C. Is There a New Alternative for a Safer Kidney Artery Ligation in Laparoscopic Donor Nephrectomy? Journal of Laparoendoscopic \& Advanced Surgical Techniques. 2017;27(7):715-6. doi: https://doi. org/10.1089/lap.2016.0271

10. Kocak B, Koffron AJ, Baker TB, Salvalaggio PRO, Kaufman DB, Fryer JP, et al. Proposed classification of complications after live donor nephrectomy. Urology. 2006;67(5):927-31. doi: https://doi.org/10.1016/j.urology.2005.11.023

11. Chan D, Bishoff JT, Ratner L, Kavoussi LR, Jarrett TW. Endovascular gastrointestinal stapler device malfunction during laparoscopic nephrectomy: early recognition and management. J Urol. 2000;164(2):31921. doi: https://doi.org/10.1016/S00225347(05)67349-1

12. Deng DY, Meng MV, Nguyen HT, Bellman GC, Stoller ML. Laparoscopic linear cutting stapler failure. Urology. 2002;60(3):415-9; discussion 419-420. doi: https://doi.org/10.1016/s00904295(02)01778-8 


\section{Polymer clips (Hem-o-lok®) for renal vessel control in laparoscopic living donor... Tena-González-Méndez G., et al.}

13. Dekel Y, Mor E. Hem-o-lok clip dislodgment causing death of the donor after laparoscopic living donor nephrectomy. Transplantation. 2008;86(6):887. doi: https://doi.org/10.1097/ tp.0b013e31818620b1

14. Ponsky L, Cherullo E, Moinzadeh A, Desai M, Kaouk J, Haber G-P, et al. The Hem-o-lok clip is safe for laparoscopic nephrectomy: a multiinstitutional review. Urology. 2008;71(4):5936. doi: https://doi.org/10.1016/j. urology.2007.11.015

15. Baumert H, Ballaro A, Arroyo C, Kaisary AV, Mulders PFA, Knipscheer BC. The Use of Polymer (Hem-o-lok) Clips for Management of the Renal Hilum During Laparoscopic Nephrectomy. European Urology. 2006;49(5):816-9. doi: https://doi. org/10.1016/j.eururo.2005.12.073

16. Bittner JG, Sajadi K, Brown JA. Comparison of renal artery occlusion techniques in handassisted laparoscopic living donor nephrectomy. J Endourol. 2009;23(6):933-7. doi: https://doi. org/10.1089/end.2008.0297
17. Siqueira TM, Mitre AI, Simoes FA, Maciel AF, Ferraz AM, Arap S. A cost-effective technique for pure laparoscopic live donor nephrectomy. Int Braz J Urol. 2006;32(1):23-8; discussion 28-30. doi: https://doi.org/10.1590/s167755382006000100004

18. Vinson AJ, Rose C, Kiberd BA, Odutayo A, Kim SJ, Alwayn I, et al. Factors Associated With Prolonged Warm Ischemia Time Among Deceased Donor Kidney Transplant Recipients. Transplant Direct. 2018;4(5):e342. doi: https:// doi.org/10.1097/txd.0000000000000781

19. Liu Y, Huang Z, Chen Y, Liao B, Luo D, Gao $\mathrm{X}$, et al. Staplers or clips?: A systematic review and meta-analysis of vessel controlling devices for renal pedicle ligation in laparoscopic live donor nephrectomy. Medicine (Baltimore). 2018;97(45):e13116. doi: https://doi. org/10.1097/md.0000000000013116

20. Chan D, Fabrizio M, Ratner L, Kavoussi L. Complications of laparoscopic live donor nephrectomy: The first 175 cases. Transplantation proceedings. 2000;32:778. doi: https://doi. org/10.1016/S0041-1345(00)00979-9 